\title{
KORČULANSKI STATUT I NJEGOVA NASLJEDNOPRAVNA REGULACIJA
}

Sažetak: Nasljednopravna regulacija Korčulanskog statuta temelji se na elementima starog hrvatskog i slavenskog prava te se razlikuje od regulacija prisutnih $u$ statutima ostalih dalmatinskih gradova koje su nerijetko posljedica utjecaja bizantskog i kasnijeg hrvatsko-mađarskog prava Tripartita. Temeljna osobina ovakvog uređenja, koje Margetić naziva descendentnim nasljednim pravom jest mogućnost da muški i ženski potomci naslijede ostavštinu umrlog, ali pri tome muški imaju prednost u odnosu na žene istog stupnja srodstva, dok prema hrvatsko-mađarskom pravu žene nisu imale mogućnost naslijediti očeve nekretnine. U nastavku rada ukazat ćemo na razlike glede pravnih temelja nasljeđivanja prisutne u Korčulanskom i drugim važnim statutima dalmatinskih gradova, a osobitu pozornost posvetit ćemo nasljednopravnom položaju udane žene u vezi s mogućnosti raspolaganja vlastitim dobrima, tj. mirazom.

Ključne riječi: $\quad$ nasljednopravna regulacija, Korčulanski statut, statuti dalmatinskih gradova, nasljednopravni položaj žene, miraz

\section{NASLJEDNO PRAVNO UREĐENJE NA PODRUČJU SREDNJOVJEKOVNE HRVATSKE}

Kako bismo jasno utvrdili razlike između pojedinih nasljednopravnih uređenja koja su u znatnoj mjeri utjecala na nasljeđivanje u srednjovjekovnim otočnim komunama u nastavku donosimo kratak pregled razvoja pravnih okvira gdje je posebna pozornost usmjerena na pravo sudjelovanja ženskih potomaka u nasljeđivanju.

Justinijanovom kodifikacijom, Corpus iuris civilis, provedeno je uređenje zakonskog nasljeđivanja, a na temelju kasnijih propisa, među ostalim, uklonjena je i smetnja ženskog naslje-

\footnotetext{
* Dr. sc. Jelena Kasap, docentica, Pravni fakultet Sveučilišta Josipa Jurja Strossmayera u Osijeku, Stjepana Radića 13, 31000 Osijek. Adresa e-pošte: jkasap@pravos.hr. ORCID: https://orcid.org/0000-0002-8182-7493.

** Dr. sc. Višnja Lachner, docentica, Pravni fakultet Sveučilišta Josipa Jurja Strossmayera u Osijeku, Stjepana Radića 13, 31000 Osijek. Adresa e-pošte: vlachner@pravos.hr. ORCID: https://orcid.org/0000-0002-8182-7493.
} 
đivanja, odnosno omogućeno je nasljedno pravo i ženskim i muškim potomcima. Justinijanovim izmjenama iz 543. i 548. godine stvoren je novi sustav nasljeđivanja u kojem je krvno srodstvo bilo glavni temelj nasljeđivanja, zatim i žene i muškarci mogli su biti i nasljednici i ostavitelji te je uklonjena razlika između osoba s obzirom na činjenicu jesu li sui iuris ili alieni iuris. Prema Justinijanovu pravu postojala su četiri nasljedna reda u kojima su vrijedila pravila da sljedeći nasljedni red nasljeđuje samo ako nema nikog iz prethodnoga ili ako se nitko od njih nije prihvatio nasljedstva (successio ordinum) i pravilo da bliži srodnik isključuje daljnjega (successio graduum) te načelo predstavljanja i obveza collatio bonorum. ${ }^{1}$

Nakon smrti Justinijana, kada je riječ o uređenju nasljednopravnih odnosa, dolazi do primjene bizantskog prava kojeg su činile norme Justinijanove kodifikacije, ali uz kasnije izmjene i dopune bizantskih careva. Ovo pravo primjenjivalo se sve do turskog osvajanja Carigrada (15. stoljeće), pa je u tom razdoblju došlo do promjene i u zakonskom nasljeđivanju. Naime, prema novom uređenju, muška i ženska djeca više nisu bila izjednačena glede nasljeđivanja jer se smatralo za kćer koja je dobila miraz da je isplaćena, i ona se zbog toga isključivala iz nasljedstva. ${ }^{2}$ Dakle, takvo je uređenje odstupalo od Justinijanova prava.

Na pravnom području koje je obuhvaćalo teritorij Istre, Hrvatskog primorja i Dalmacije vrijedilo je rimsko-bizantsko pravo, pa tako i nasljedni sustav prema kojem je dominiralo načelo o potpunoj izjednačenosti muške i ženske djece u slučaju neoporučnog nasljeđivanja. Ovaj sustav našao se između langobardskog i hrvatsko-ugarskog sustava.

Sustav neoporučnog nasljeđivanja u kojem su izjednačeni muški i ženski potomci prevladavao je u srednjovjekovnoj Dalmaciji i to u sustavima Krka, ${ }^{3}$ Raba, ${ }^{4}$ Cresa, ${ }^{5}$ Splita, Budve ${ }^{6}$ te možda u jednoj od ranijih faza razvoja prava u Dubrovniku. ${ }^{7}$ Tako se u odredbi Splitskog statuta navodi da ako netko umre bez oporuke i ako ima mušku ili žensku djecu, tada sinovi i kćeri nasljeđuju na jednake dijelove. ${ }^{8}$ Sličnu odredbu da očevu ostavštinu moraju dobiti sinovi,

1 Romac, A., Rimsko pravo, Pravni fakultet: Centar za stručno usavršavanje i suradnju s udruženim radom, Zagreb, 1981., str. 368.-370. Nov. 118 pr. cap. 4: Plurimas et diversas leges veteribus temporibus prolatas invenientes, per quas non iuste differentia $a b$ intestato successionis inter cognatos ex masculis et feminis introducta est, necessarium esse perspeximus omnis simul ab intestato cognationum successiones per praesentem legem clara compendiosaque divisione disponere, itaque prioribus legibus pro hac causa positis vacantibus de cetero ea sola servari quae nunc constituimus. Quia igitur omnis generis ab intestato successio tribus cognoscitur gradibus, hoc est ascendentium et descendentium et ex latere, quae in agnatos cognatosque dividitur, primam esse disponimus descendentium sucsessionem. Citirano prema: Puchta, G. F., Pandekten, Leipzig, 1848., str. 600. Opširnije u: Romac, A., Izvori rimskog prava latinski tekstovi s prijevodom, Informator, Zagreb, 1973., str. 476.-479., Sohm, Rudolf, The Institutes of Roman Law, Chapter II, The law of inheritance, Translated by James Craford Ledlie, Oxford and the Claredon Press, 1892., str. 408.-437., Kaser, M., Das römische Privatrecht, Erster Abschnitt: Das altrömische, das vorklassische und das klassische Recht, Munich: C. H. Beck, 1955. str. 566.-567.

2 Margetić, L., Nasljedno pravo descendenata po srednjovjekovnim statutima Šibenika, Paga, Brača i Hvara, Zbornik Pravnog fakulteta u Zagrebu, god. 22, br. 3, Zagreb, 1972., str. 349.

3 Krčki (Vrbanski) statut, knj. II., gl. 20., Krčki (Vrbanski) statut iz 1388. / Lujo Margetić, Petar Strčić, Povijesno društvo Saveza povijesnih društava Hrvatske, Krk, 1988.

4 Rapski statut, knj. II., gl. 10., 17. Margetić, L., Statut rapske komune iz 14. stoljeća = [Statut communis Arbae], Adamić, Rab, Grad Rab, Rijeka, 2004.

5 Creski statut, gl. 67. Statuto di Cherso et Ossero, Venetiis, 1640.; Beuc, I., Osorska komuna u pravnopovijesnom svjetlu, Vjesnik historijskih arhiva u Rijeci i Pazinu, god. 1., br. 1953., Državni arhiv u Rijeci - Državni arhiv u Pazinu, Pazin, 1953., str. 141.-145.

6 Budvanski statut, gl. 212. Ljubić, Š., Statuta et leges civitatis Buduae, civitatis Scardonae et civitatis insulae Lesinae, Zagreb, 1882./1883.

7 Margetić, L., Hrvatsko srednjovjekovno obiteljsko i nasljedno pravo, Zagreb, 1996., str. 225.

8 Splitski statut, III., 44. Cvitanić, A. (ed.), Statut grada Splita, Statuta civitatis Spalati, II. dotjerano izdanje, Književni krug, Split, 1987. Vidjeti Cvitanić, A., Iz dalmatinske pravne povijesti, Split, 2002., str. 199.-200. 
a ako njih nema, kćeri, nalazimo i, barem neko vrijeme, u Statutu Trogira. ${ }^{9}$ Problem izjednačenosti muških i ženskih descendenata pojavljuje se i u Dubrovačkom statutu. Iz nekih odredaba Dubrovačkog statuta proizlazi načelo o izjednačenosti spolova i to na način da potomci dviju ili više žena, bilo oni muški ili ženski, trebaju međusobno podijeliti i pokretnu i nepokretnu imovinu svoga oca na jednake dijelove. ${ }^{10}$ Shodno tome, navodi se i da braća i sestre mogu podijeliti među sobom očevinu za života majke koja vjerno čuva mužev krevet i protiv njezine volje. ${ }^{11}$ Međutim, autori koji su se u okviru istraživanja bavili problematikom obiteljskih odnosa u srednjovjekovnom dubrovačkom pravu navode da sestre uz braću nisu bile nasljednice te da je miraz jedina imovina koju je kći posredno mogla naslijediti. Tako V. Čučković tumači odredbu gl. 79. knj. IV. Statuta, prema kojoj najmlađi brat dijeli kuće, zemljišta blizu grada itd., pa nakon toga brat izabire svoj dio, a nakon njega redom braća prema dobi, odnosno tek ako sestre nemaju rođene braće, priznaju im se sva prava koja su Statutom priznata sinovima. ${ }^{12}$ Prema Čučković, u slučaju postojanja muškog potomstva kćeri ne sudjeluju u diobi ostavinske mase. Suprotno navedenom stajalištu, L. Margetić smatra da bi se odredba gl. 79. trebala primjenjivati samo u slučajevima kada otac ima samo mušku ili samo žensku djecu, dok bi se odredba gl. 25. primjenjivala u slučaju postojanja i sinova i kćeri. ${ }^{13}$

Drukčiji sustav nasljeđivanja prihvaćen je u srednjovjekovnim komunama Paga, Šibenika, Brača i Hvara. Tako je bilo propisano da sinovi u navedenim pravnim sustavima nasljeđuju gradske kuće, dok su u ostalim pravima bili izjednačeni muški i ženski potomci. Prema Paškom statutu bilo je propisano da muška i ženska djeca dijele na jednake dijelove očevu i majčinu ostavštinu, osim očevih kuća koje se nalaze na Pagu koje trebaju isključivo pripasti sinovima i njihovim muškim potomcima. ${ }^{14}$ Identične odredbe možemo naći i u Šibenskom statutu, prema kojem su roditelji mogli ostaviti nekom od svojih potomaka četvrtinu vrijednosti pokretnina i nekretnina, osim kuća i stvari kućanstva koje je bilo zabranjeno davati kćerima. ${ }^{15}$ Slične odredbe nalazimo i u Bračkom te Hvarskom statutu. Naime, prema Statutu bračke komune bilo je određeno da ako roditelj umre bez oporuke, tada njegovu imovinu dijele na jednake dijelove muška i ženska djeca, osim stambenih zgrada koje trebaju pripasti samo muškim potomcima. ${ }^{16}$ Shodno tome, identičnu odredbu sadrži i Hvarski statut. ${ }^{17}$ Također, L. Margetić navodi

$9 \quad$ Statut Trogira, knj. III., gl. 16. Berket, M. et al. (eds.), Statut grada Trogira, Statuta et refomationes cicitatis Traguirii, Književni krug, Split, 1988.

10 Dubrovački statut, knj. IV., gl. 25., 35. Šoljić, A., Šundrica, Z., Veselić, I., Statut grada Dubrovnika, Državni arhiv u Dubrovniku, Dubrovnik, 2002.

11 Dubrovački statut, knj. IV., gl. 21.

12 Dubrovački statut, knj. IV., gl. 79. Čučković, V., Porodica i porodični odnosi u srednjovjekovnom Dubrovniku, Godišnjak Pravnog fakulteta u Sarajevu, br. 31., 1983., str. 272.

13 Margetić, op. cit. u bilj. 7, str. 233.

14 Paški statut, knj. V., gl. 18. Čepulo, D., Statut Paške općine, Statuta Communitatis Pagi, Zagreb, 2011. Vidjeti: Margetić, op. cit. u bilj 2, str. 339.-366.

15 Šibenski statut, knj. V., gl. 22.-24. Isti, knj. 4., gl. 64. Grubišić, S. (ed.), Knjiga statuta, zakona i reformacija grada Šibenika, Muzej grada Šibenika, Šibenik, 1982.

16 Brački statut, knj. I, gl. 23. Cvitanić, A. (ed.), Brački statut, Drugo prošireno dopunjeno i dotjerano izdanje, Književni krug, Split, 2006. 
i da je stari Zadarski statut, koji je važio prije 1305., sadržavao odredbe na temelju kojih su ženska djeca nasljeđivala uz sinove u prvom nasljednom redu. ${ }^{18}$

Različito od navedenih odredaba, bilo je u Zadarskom ${ }^{19}$ i Trogirskom statutu ${ }^{20}$ koji su usvojili mletački sustav nasljeđivanja iz Mletačkog statuta Jakova Tiepola iz 1242., a prema kojem su sinovi nasljeđivali nekretnine, a kćeri pokretnine zajedno sa sinovima. ${ }^{21} \mathrm{U}$ Trogirskom statutu bilo je propisano da ako ostavitelj ima mušku i žensku djecu, tada su sinovi nasljeđivali nekretnine, a kćeri pokretnine u visini "dostojnog" miraza. ${ }^{22}$

Prema tzv. barbarskom sustavu koji se održao u kontinentalnom dijelu Apeninskog i Balkanskog poluotoka, a u 13. stoljeću i proširio na neka područja rimsko-bizantskog sustava (u Zadar u 14. st., u Trogir u 15. st.), najprije su pravo nasljeđivanja imali muški potomci, a ako njih nije bilo, na red su dolazili ženski potomci. ${ }^{23}$ Nasljedno pravo korčulanskog pravnog područja pokazuje neke osobitosti koje nisu svojstvene spomenutim hrvatskim pravnim područjima, a koje Margetić s razlogom naziva hrvatskim odnosno slavenskim tipom descendentnog nasljeđivanja. Kako bi se što potpunije utvrdile osobitosti tog pravnog sustava nasljeđivanja, u nastavku će se posebna pozornost posvetiti raščlambi posebnih obilježja pojedinih sustava nasljeđivanja koji su bili relevantni u hrvatskom srednjovjekovnom pravu.

Na hrvatsko-slavonskom području nasljedno pravo plemstva i seljaka bilo je uređeno Tripartitom, koji je predstavljao kodifikaciju hrvatsko-ugarskog prava i običaja. S druge strane, nasljeđivanje građana bilo je uređeno posebnim propisima. ${ }^{24}$ Navedeni se sustav nasljeđivanja počeo širiti hrvatskim pravnim područjem počevši od dvanaestog stoljeća usporedno sa širenjem hrvatsko-ugarske vlasti na istom području, tj. u smjeru Zadra i Splita. ${ }^{25}$

Za razliku od rimsko-bizantskog sustava nasljeđivanja, prema odredbama Tripartita koje se odnose na nasljednopravno uređenje plemstva, pripadnice ženske loze nisu bile izjednačene glede nasljeđivanja u odnosu na mušku lozu. Naime, vrijedilo je pravilo da nekretnine nasljeđuju samo muška djeca, ali je postojala i iznimka prema kojoj je bila pružena mogućnost nasljedstva i ženskoj lozi. Tako je za nekretnine stečene kraljevskom darovnicom bilo određeno da ih i ženska djeca mogu naslijediti, ako nisu bila isključena od nasljeđivanja voljom prvog stjecatelja. Ovdje se podrazumijevalo jednako pravo na nasljedstvo srodnika muške i ženske

18 Margetić, L., Neoporučno nasljedno pravo u srednjovjekovnoj Istri, Vjesnik historijskih arhiva u Rijeci i Pazinu, vol. 17, 1972., str. 164.

19 Zadarski statut, knj. III., gl. 127.-129. Kolanović, J., Križman, M. (eds.), Statuta Iadertina, Zadarski statut sa svojim reformacijama odnosno novim uredbama donesenima do godine 1563, Zadar 1997.

Trogirski statut, ref. knj. II., gl. 22

21 Margetić, op. cit. u bilj. 7, str. 225.

22 Trogirski statut, ref. knj. II., gl. 22. Vidjeti: Radić, Ž., Imovinsko pravo po statutu grada Trogira iz 1322. (doktorska disertacija), 2002., str. 268.

23 Margetić, op. cit. u bilj. 2, str. 360. Kada je riječ o nasljeđivanju ženskih potomaka prema drugim izvorima koji su vrijedili tijekom srednjeg vijeka na području germanskih zemalja, vidjeti: Hübner, Rudolf, A History of Germanic Private Law, The Lawbook Exchange, Ltd., New Yersey, 2000., Chapter XV., str. 712.-732. Sydow, Rudolf von, Darstellung des Erbrechts nach den Grundsätzen des Sachsenspiegels mit Rücksicht auf die verwandten Quellen, Berlin, 1828., str. 81., 92.-93. Više vidjeti u sadržaju odredbe Sachsenspiegel, I, 5 § 2, i I, 13, § 1. Citirano prema: Kaller, Paul, Der Sachsenspiegel in hochdeutscher Ubersetzung, Verlag, C. H. Beck, München, 2002. 
loze. Isto tako, i za stečena dobra (tzv. bona acquisita), ako je riječ o nekretninama, vrijedilo je pravilo da ih nasljeđuju samo muški potomci. Međutim, ako su nekretnine kupljene od roditelja, vrijedila je jednakopravnost u nasljeđivanju. Isto pravilo primjenjuje se i u slučaju pokretnina, novca i založenih plemićkih posjeda. Stoga, pravo nasljeđivanja imala je i muška i ženska loza potomaka na jednake dijelove. ${ }^{26}$

Sličan način nasljeđivanja kao kod plemića, odnosio se i na gradsko stanovništvo srednjovjekovne Hrvatske. Naime, prema odredbama Zlatne bule Andrije II. iz 1222. i odluci Slavonskog sabora iz 1273., može se zaključiti da su u gradovima nasljeđivali samo sinovi te da kćeri nisu smatrane nasljednicima. ${ }^{27}$ Međutim, situacija je posve drukčija ako se promotre odredbe Iločkog statuta i privilegija Gradeca. ${ }^{28}$ Naime, prema tumačenju spomenutih izvora postojala je jednaka mogućnost nasljeđivanja za braću i sestre, ali i za bračnog druga. Iločki statut sadrži odredbu prema kojoj u slučaju diobe nasljednih dobara, nakon smrti oca, svaki član obitelji stječe pravo na jednaki dio i nekretnina i pokretnina. ${ }^{29} \mathrm{~S}$ obzirom na to da iz ove odredbe proizlazi kako se ista odnosila i na nekretnine i pokretnine, može se zaključiti da je glede nasljeđivanja građanskih nekretnina postojao drukčiji sustav, nego u odnosu na plemićke nekretnine. Valja konačno zaključiti kako je, prema Tripartitu, glede nasljednopravnog režima kmetskih nekretnina vrijedio isti sustav nasljeđivanja kao i kod nasljeđivanja plemićkih nekretnina. ${ }^{30}$

Temelj pravne regulacije nasljednog prava zagrebačkog Gradeca svakako su norme privilegija, no praksa 14. i 15. stoljeća znatno je utjecala na razvoj nasljedno-pravnog uređenja te je time sasvim sigurno utvrdila nov sustav pravnog reguliranja ovog pitanja. Prema istraživanju Apostolove Maršavelske pravna je praksa izmijenila temeljna načela zastupljena u privilegijima. Suprotno od pravila utvrđenih u privilegijima žena je bila nasljednik muškog ostavitelja zajedno s djecom ostavitelja neovisno o tome kojeg su bila spola, a djeca su nasljeđivala ostavitelja neovisno o spolu u jednakim dijelovima. ${ }^{31}$ Ovakav sustav nasljeđivanja nesporno je afirmiran snažnim utjecajem običajnog prava koje je u nekim slučajevima ipak odstupalo od dominantnih pravnih utjecaja.

Tri su hrvatske priobalne komune usvojile poseban tip nasljednog prava descendenata koje Margetić naziva starim hrvatskim nasljednim pravom. To su Vinodolski zakon iz trinaestog, Poljički statut iz petnaestog stoljeća te Korčulanski statut kojem će se veća pozornost posvetiti u nastavku. Kako su navedene komune usvojile sustav nasljeđivanja koji je odstupio od nasljednog prava koje je vrijedilo na ostatku priobalnog, ali i kontinentalnog srednjo-

26 Lanović, op. cit. u bilj. 24, str. 307.-313.

27 Odluka Slavonskog sabora koja se odnosi na nasljedno pravo vidljiva je u odluci br. 8. prema kojoj nasljedni dio onoga tko umre bez nasljednika treba naslijediti njegova općina (generacioni sue). Unutar plemićkih općina postojalo je, dakle, pravilo prema kojem nekretnine ostavitelja umrlih bez nasljednika nisu postajale ošasnima i nisu pripadale kralju. Plemićka općina predstavljala je zajednicu povezanu zajedničkim pretkom. Vidjeti: Margetić, L., Apostolova Maršavelska, M., Hrvatsko srednjovjekovno pravo: vrela s komentarom, Narodne novine, Zagreb, 1991., str. 85. i 87. Margetić, L., Iločka pravna knjiga, Zbornik Pravnog fakulteta u Zagrebu, br. 1-2, Zagreb, 1994., str. 93.-116.

29 Zdravčević, A., Iločki statut iz 1525. godine i njegova nasljedno pravna regulacija, doktorski rad, Osijek, 1993., str. 89.-92.; Više o nasljednopravnim obilježjima Iločkog statuta vidjeti u knjizi IV., Statut grada Iloka, Separat iz godišnjaka Matice hrvatske Vinkovci, Vinkovci, 1970.; Nadalje, mogućnost da žene nasljeđuju, ali i raspolažu vlastitom imovinom, prema Iločkom statutu, obilježje je nasljednog prava koje je vrijedilo isključivo na iločkom području. Vidjeti odredbu glave 4., knjige IV. 
vjekovnog hrvatskog teritorija, nastojat će se utvrditi podrijetlo i posebnosti takvog sustava nasljeđivanja.

Prema odredbama čl. 32. Vinodolskog zakona ostaviteljevu imovinu nasljeđivali su u pravilu sinovi te ostali muški descendenti, a ako ih nije bilo, knez je odlučivao hoće li kćeri prihvatiti za nasljednike, a iza kćeri ostavina je pripadala njihovoj muškoj djeci. ${ }^{32}$ Neovisno o nasljednom pravu, žena je uživala muževu ostavinu za vrijeme života. ${ }^{33}$ Zadržavanje pravnih pravila koja su bitno odstupala od regulacije nasljednog prava na ostalim hrvatskim područjima u razdoblju na koje su u radu referiramo, a koja su se razvila pod utjecajem tripartitnog prava, posljedica je autonomije krčkih knezova koja je isključivala ingerenciju državnih vlasti na tom pravnom području. ${ }^{34}$ Slična je regulacija vrijedila i na području Poljica s obzirom na to da nisu neprijeporno usvojila hrvatsko ugarsko vrhovništvo te su dijelom zadržala staru pravnu regulaciju. Tekst čl. 100.c izričito otvara mogućnost da ostaviteljevu imovinu naslijede i muški i ženski nasljednici, premda je prednost pri nasljeđivanju dana muškim nasljednicima iste rodbinske udaljenosti. ${ }^{35} \mathrm{Na}$ sličnim je temeljima izgrađena regulacija iste problematike $\mathrm{u}$ odredbama Korčulanskog statuta koje se detaljnije analiziraju u nastavku. Može ih se svesti na jedno zajedničko obilježje, a to je pravo ženskih nasljednika da pod određenim okolnostima ipak sudjeluju u nasljeđivanju umrlih ostavitelja. Navedeno očigledno predstavlja iznimku od pravila zastupljenog u dominantnim izvorima srednjovjekovnom hrvatskog prava koji su isključivo favorizirali muške nasljednike.

Prema mišljenju Margetića, nasljednopravna regulacija triju spomenutih statuta bez sumnje je utemeljena na recipiranim odredbama langobardskog prava. ${ }^{36}$ Prema odredbama langobardskog prava ženski su potomci mogli naslijediti umrlog ostavitelja samo ako ostavitelj nije imao zakonitog sina. ${ }^{37}$ Premda neposredna primjena langobardskog prava na hrvatskom pravnom području nije dosljedno provedena ni u kojem razdoblju hrvatske pravne povijesti, nema sumnje da je izgradnja hrvatskog pravnog sustava u vrijeme narodnih vladara, kada je riječ o nekim terminima i ustanovama, ipak usvojila susjedne utjecaje. ${ }^{38}$

Obilježje nasljednog prava prema kojem ženski potomci nasljeđuju umrlog ostavitelja nije neuobičajeno u srednjovjekovnim kodifikacijama prava nekih germanskih naroda. Tako su, primjerice, vizigotskim pravom ženski nasljednici izjednačeni s muškima ako roditelji nisu

32 Margetić, op. cit. u bilj. 7, str. 275.

33 Članak 32. Vinodolskog zakonika glasi: “(...) kćere ke su ostale po smerti očini i materini ili sini ako nisu ostali brati tem kćeram, imaju se areditati ili ostaviti tim kćeram blago otčino i materino, čineći vsu službu onu, ku esu imili služiti dvoru otci i matere njih.- I takoe, ako bi sini ostali i umerli bez reda." Margetić, L., Vinodolski, Adamić - Vitagraf, Rijeka - Novi Vinodolski, 1998.

Vidjeti čl. 100.a i c, u: Pera, M., Poljički statut, Književni krug, Split, 1988.

1. I. Si quis langobardus sine filiis masculinis legetimis mortuos fuerit, et filias dereliquerit, ipsae ei in omnem hereditatem patris uel malris suae, tamquam fiii legetimi mascolini, heredis succedant., 2. II. Si quis langobardus se uiuente filias suas nupto tradederit, et aiias filias in capillo in casa reliquerit, tunc omnes aequaliter in eius substantia heredis succedant, tamquam filii masculini. Friedrich Bluhme, Edictus ceteraeque Langobardorum leges: cum constitutionibus et pactis principum Beneventanorum, Hannover, 1869, p. 86. U nastavku: Edictus langobardorum leges. https://archive.org/details/edictusceteraequ00bluh/page/n4. Više o temeljnim osobitostima langobardskog nasljednog prava vidjeti: Hübner, R., A History of Germanic Private Law, The Lawbook Exchange, Ltd., New Yersey, 2000., str. 759. 
drukčije odredili oporukom..$^{39}$ Ostali izvori germanskih naroda ograničili su mogućnost nasljeđivanja ženskim potomcima samo na one slučajeve u kojima nije bilo muških nasljednika. U nekim slučajevima, ipak, germanski su narodi favorizirali ženske nasljednike. Primjerice, Lex Burgundionum posebno regulira slučaj nasljeđivanja ženskih potomaka, sestara, koje su isključivo nasljeđivale sestru umrlu prije zaključenja braka. ${ }^{40}$ Majčin nakit, kao vrijednu pokretninu, također su mogle naslijediti samo njezine kćeri. ${ }^{41}$

\section{OBITELJSKOPRAVNO UREĐENJE KORČULANSKOG STATUTA}

Iako obiteljsko-pravni i bračni odnosi nisu pobliži predmet interesa ovog rada, držimo važnim osvrnuti se u kratkom uvodu na statutarnu regulaciju navedenih odnosa kako bi se, $u$ nastavku, na iste odnose mogla primijeniti problematika nasljeđivanja. Već na samom početku korisno je napomenuti kako su obiteljski odnosi na području korčulanske komune uređeni pod snažnim utjecajem crkvenog prava te stare romanske tradicije. ${ }^{42}$

Čini se nespornim da je otac vrhovna vlast u obitelji, osobito u odnosu na djecu. Takav je položaj oca čest i u ostalim statutima dalmatinskih gradova. ${ }^{43}$ Ako je sin želio napustiti obitelj s namjerom oslobođenja od očinske vlasti i samovolje, u potpunosti je gubio nasljedni dio i o volji roditelja je ovisilo hoće li mu za života ostaviti neki dio imovine. Ista se odredba odnosila i na žensku djecu, a odredbom iz knjige Reformacija osobito je s tim u vezi naglašena neposlušnost sinova i kćeri te zabrana budućih promjena odredaba statuta ili zakona kojom bi se primjena ovakve odluke stavila izvan pravne snage. ${ }^{44}$ Položaj sina pod očevom vlašću još je vidljiviji u glavi 47. Statuta gdje se ističe kako svaki dobitak ili gubitak koji je sin ostvario trgovinom ide u korist ili na štetu te iste imovine. Ali, ako sin nije trgovao uz očev pristanak, gubitak nije smio teretiti očevu imovinu. ${ }^{45}$ Položaj oca kao glave obitelji pravilo je u svim izvorima hrvatskog srednjovjekovnog prava iz čega vrlo eksplicitno proizlazi važnost ovog instituta u uređenju imovinskopravnih odnosa unutar obitelji koji će se nastojati prikazati u nastavku.

Uzme li se u obzir ograničenje poslovne sposobnosti udane žene koja je čak i glede svoje imovine smjela ugovarati samo uz mužev pristanak, može se zaključiti kako je i žena za vrijeme muževa života bila pod njegovu vlašću. No, nakon smrti muža položaj žene se prema

39 Leges Visigothorum, IV, 2, 1, M. Bennett, J., Karras, R. M. (edc.), The Oxford Handbook of Women and Gender in Medieval Europe, Oxford University Press, Oxford, 2013., § Women and property.

40 Lex Burgundioum, XLII. Peyré, Jean François Aimé: M. J. F. A. Peyré (ed.), Lex Burgundionum Lois des Bourguignons, vulgairement nommées Loi Gombette, traduites pour la première sois, Lyon, 1855., https://reader.digitale-sammlungen.de/de/fs1/object/display/ bsb10551887-00005.html, pristupljeno 11. travnja 2019.

41 Lex Burgundioum, LI., 4.-5.

42 Cvitanić, A., Iz dalmatinske pravne povijesti, Književni krug Split, 2002., str. 598. U cijelosti su obiteljskopravni odnosi komune obilježeni starim slavenskim pravom koje se ističe starješinstvom roditelja u odnosu na djecu i obiteljskim vlasništvom. Cf. ibid., str. 598.

43 Kao primjer statuta u kojem je osobito strogo naglašena uloga pater familias navodimo Dubrovački statut prema kojem je otac imao pravo čak i primiti miraz sinove žene u korist svoje imovine. Statut grada Dubrovnika, knjiga četvrta, glava XII, str. 254.

44 Korčulanski statut: Statut grada i otoka Korčule iz 1214. godine, preveo i pripremio Cvitanić, A., Zagreb - Korčula, 1987. (u nastavku Korčulanski statut). Reformacije Korčulanske komune, glava CXLV. 
odredbama Statuta drastično mijenja, a pobliže objašnjenje njezina položaja pronašli smo u dvjema odredbama. Prvoj koja regulira položaj žene, tj. udovice nakon muževe smrti te joj daje pravo, pod uvjetom da se ponovno ne uda, zadržati cjelokupnu muževu imovinu te svoj miraz. ${ }^{46}$ Odredba izričito imenuje udovicu gospodaricom te joj zabranjuje svjesno raspolaganje kojim bi se imovina uništila. Osobito je važno za pitanje pravnog položaja žene spomenuti nastavak statutarne odredbe kojim se ograničava vrijednost imovine kojoj žena može postati gospodarica. Naime, ako bi imovina koju je žena imala pravo naslijediti prelazila njezine potrebe, Kurija je u punom sastavu imala pravo dodijeliti joj imovinu potrebnu za odijevanje $\mathrm{i}$ ishranu, a ostatak imovine dodijeliti najbližem srodniku ostavitelja koji u tom slučaju nije oporučno raspolagao. Čini se kako se ženi ipak nije davalo osobito povjerenje glede mogućnosti gospodarenja vrijednom imovinom, nego ju se ograničavalo na način da joj se osiguravala samo imovina dostatna za egzistenciju. Možda je, s tim u vezi, kontrarna odredba koju pronalazimo u već spomenutoj glavi 47. Statuta koja u slučaju očeve smrti izričito imenuju ženu gospodaricom obiteljske imovine. ${ }^{47}$

Različito od imovine žene imovina bračnih drugova u odredbama Statuta je odvojena. Ženina se ponajprije sastojala od miraza, koji su osiguravali njezini roditelji ili bliži krvni srodni$\mathrm{ci}^{48}$ Statut nije uredio način utvrđivanja visine miraza, no forma je bila određena. ${ }^{49} \check{C}_{\text {ini se da }}$ je 1412. godine utvrđeno kako o svakom mirazu koji dobije žena unutar komune mora biti sastavljena isprava u roku od jedne godine nakon sklapanja braka, u suprotnom, ako isprava ne bude sastavljena, nije se smjelo svjedočenjem utvrđivati suprotno od onog što je htio protivnik onog u čiju se korist svjedoči. ${ }^{50} \mathrm{Na}$ prvi pogled može se steći dojam kako je miraz predstavljao jedini oblik ženina vlasništva za vrijeme muževa života jer je mirazom imala pravo samostalno raspolagati. No, odredbe novije redakcije Statuta (donesene 1389.) u potpunosti opovrgavaju ovakav pristup. Pravo raspolaganja mirazom žena je imala samo u tri slučaja: za otkup muža iz zatvora (ako drukčije nije mogao izaći) i uz dopuštenje Kurije da na taj način raspolaže mirazom, potom radi izbavljenja sina ili sinova iz zatvora kao i u prethodnom slučaju i konačno u slučaju kada žena zajedno sa sinovima i kćerima trpi glad te smije otuđiti imovinu samo uz slobodnu ocjenu komunalne uprave. ${ }^{51}$ Sukladno sadržaju navedenih odredaba, premda se miraz u srednjovjekovnom pravu smatrao ženinom imovinom, ženi je u srednjovjekovnoj korčulanskoj komuni bilo dopušteno samostalno raspolagati svojim mirazom samo u iznimnim situacijama, tj. s točno određenom svrhom koja je značila egzistencijalnu prijetnju članovima njezine obitelji i s određenom procedurom, tj. samo uz dopuštenje komunalnih vlasti. U slučaju kada je imala dopuštenje supruga za raspolaganje mirazom ili ona raspolaganja koja je učinio muž uz ženinu suglasnost, tj. prodaja, zalaganje, darovanje ili drugi pravni poslovi koji su bili valjani i načelno neograničeni svrhom otuđivanja ili odobrenjem komunalnih tijela vlasti. ${ }^{52}$

46 Korčulanski statut, glava XLII., str. 46.-47.

47 Korčulanski statut, nova redakcija, glava XLVII., str. 48.

48 Cvitanić, op. cit. u bilj. 42, str. 599.

49 Drugi statuti dalmatinskih gradova utvrdili su načine određivanja visine miraza.

50 Korčulanski statut, Reformacije korčulanske komune, glava CXXIV., str. 124.

51 Korčulanski statut, glava CXL., str. 77.

52 Korčulanski statut, glava CXL., str. 77. Sličnu odredbu koja je ženi dopuštala raspolaganje mirazom samo uz muževu suglasnost sadrži i Trogirski statut, no trogirska odredba nije odredila iznimne slučajeve u kojima se mirazom moglo raspolagati samo u iznimnim slučajevima. No, izričito su navedeni knez i kurija kao tijela komunalne vlasti koja su vjerojatno ograničavala raspolaganje mirazom koje nije bilo (egzistencijalno) opravdano. Statut grada Trogira, knjiga II., glava 23., str. 139. 
Neravnopravnost žene u bračnoj zajednici osobito dolazi do izražaja pri ženinoj mogućnosti oporučnog raspolaganja vlastitim mirazom. Ograničenje raspolaganja mirazom u korist osoba koje su joj miraz dale proizlazi iz sadržaja odredbe prema kojoj žena koja nije imala potomaka, ni muških ni ženskih, nije mogla raspolagati s više od jedne trećine drugim osobama, čak ni mužu. Drukčije je pak određeno odredbama Statuta u slučaju kada je žena imala potomke. Ako su potomci umrli u dječjoj dobi, ženi je bilo dopušteno polovinu miraza ostaviti mužu, a drugu polovinu vratiti onima koji su dali miraz. ${ }^{53}$ Kako su glede oporučnog raspolaganja mirazom pri primjeni odredaba o mirazu novije redakcije Statuta očigledno postojale nesuglasice, zakonodavac je to pitanje odlučno riješio u reformacijama Statuta. ${ }^{54}$ Novom je odredbom žena koja nije imala potomaka ograničena raspolagati s dvije trećine svojeg miraza koji se redovito vraćao njezinoj obitelji, dok je preostalom trećinom raspolagala prema vlastitoj volji. U knjizi Reformacija uz statut doznaje se kako odluka o ograničenju ženina oporučnog raspolaganja mirazom u Vijeću nije jednoglasno prihvaćena. Dvadeseti šest od ukupno šezdeset vijećnika glasovalo je protiv njezina usvajanja. Navedena okolnost jasno upućuje na to kako se svijest glede položaja žene unutar obitelji, kao i njezinih imovinskopravnih raspoložbi mijenjao razmjerno s protekom vremena. Međutim, običajni elementi i dalje su se nametnuli kao dominantan regulator njezina pravnog položaja.

O tomu da je miraz predstavljao aktivu koja se prenosila s jedne na drugu generaciju te da je posredno predstavljao obiteljsku imovinu svjedoči i odredba koja je uredila pravni status miraza nakon smrti žene kojoj je pripadao. Suprug kojem je umrla supruga, u Statutu označen kao udovac, zadržavao bi ženin miraz pod uvjetom da se ponovno ne oženi. Čini se kako je bio obvezan žensku djecu udati, ako su bile u dobi za udaju, a ako se nisu željele udati, bio im je obvezan dati dio miraza koji otpada na njih. ${ }^{55}$ Nije jasno je li dio predstavljao ukupnost nasljednog dijela pojedine kćeri ili dio miraza koji je imao otpasti na njih. Skloni smo zauzeti stav kako je smisao odredbe ipak ograničen na miraz. Unatoč tomu, u nastavku odredbe vidimo da se miraz imao jednako raspodijeliti između muške i ženske djece, ako ih je bilo. No, i pravo muževa raspolaganja mirazom bilo je ograničeno. Ako je žena pri raspolaganju mirazom morala dobiti odobrenje komunalnih vlasti, čini se da muž nije mogao raspolagati mirazom bez pristanka srodnika koji su miraz u pravilu dali.

\section{NASLJEDNOPRAVNO UREĐENJE KORČULANSKOG STATUTA}

Korčulanski statut poznaje dva osnovna pravna temelja nasljeđivanja, bezoporučno tj. statutarno i u Statutu zastupljeno oporučno raspolaganje ostavitelja imovinom. Koji je pravni temelj bio pravilo, a koji iznimka te je li se oporučivati moglo slobodno i bez ograničenja u srednjovjekovnoj komuni, obrazložit ćemo u nastavku. Također, kako bi pravne konzekvence karakterističnog tipa hrvatskog tj. slavenskog descendentnog nasljeđivanja, kako ga naziva

\footnotetext{
53 Korčulanski statut, Reformacije korčulanske komune, glava CL., str. 135.

54 Korčulanski statut, Reformacije korčulanske komune, glava CL., str. 135.

55 Korčulanski statut, glava XLIII., str. 47.
} 
Margetić, ${ }^{56}$ bilo moguće u potpunosti razumjeti u nastavku će se ovaj model nasljeđivanja nastojati komparirati s modelima prisutnim u nekim drugim dalmatinskim komunama.

Tumačiti odredbe o nasljeđivanju korčulanskog Statuta primarno zahtijeva pojašnjenje terminologije koja se koristi u naizgled različitim odredbama dviju redakcija Statuta.

U staroj redakciji Korčulanskog statuta odredba kojom se reguliralo zakonsko nasljedno pravo, a koja je istodobno imala značaj utvrditi nužne nasljednike i visinu njihova nasljednog dijela, unesena je pod naslovom "O oporuci", ${ }^{57}$ a isti sadržaj u novoj redakciji Statuta naslovljen je s "Dioba (nasljedstva među) potomcima". ${ }^{58}$ Jasno je kako prvi naslov nije odgovarao sadržaju odredbe jer se činilo kako u staroj redakciji postoji samo jedan temelj nasljeđivanja, tj. oporuka. Premda je starija odredba neovisno o naslovu utvrđivala i nužne nasljednike, promjeni naslova se pristupilo tek u novoj redakciji Statuta iz sadržaja kojem se na očigled može utvrditi i postojanje nužnog, tj statutarnog nasljednog prava.

Korčulanski se statut ubraja među srednjovjekovne izvore, koji, kada je riječ o nasljednim dijelovima pojedinih nasljednika, strogo zabranjuje preferiranje pojedinih nasljednika pri nasljeđivanju umrlog ostavitelja. Valja napomenuti kako je načelo nepreferiranja pojedinih nasljednika više pravilo, no iznimka u ostalim dalmatinskim statutima, a korčulanski Statut ga nastoji individualizirati na sljedeći način. Smrću ostavitelja koji je imao jednog ili više zakonitih sinova od jedne ili više supruga koje su s njim bile u braku, nastajala je pretpostavka za nasljeđivanje sinova, u pravilu, u jednakim dijelovima ostaviteljeve imovine, neovisno o tomu je li ostavitelj sačinio oporuku ili ne. Stječe se dojam kako je oporuka samo instrument podjele ostavine ostavitelja među sinovima. ${ }^{59}$ Što i ne iznenađuje ako uzmemo u obzir da Statut ne poznaje razliku između dvaju instituta, ordinatio i testamentum, gdje je ostavitelj oporukom morao raspolagati u korist legitimnih nasljednika, ponajprije, svoje djece. ${ }^{60}$ Ipak, čini se kako nepreferiranju nije bilo mjesta u slučaju kada su ostavitelja nasljeđivali i nasljednici ženskog spola. Tada je ostavitelju bilo dopušteno oporučno raspolagati imovinom u korist sinova. Iz sadržaja odredbe proizlazi kako je ostavitelju bilo dopušteno oporukom isključiti ženske nasljednike ako se time favoriziralo nasljednike muškog spola dok preferiranju nasljednika unutar istog spola, nije bilo mjesta. Valja imati na umu kako ova odredba proizlazi iz knjige reformacija Statuta te je zasigurno napisana kako bi ispravila nejasnoće koje su se mogle pojaviti pri tumačenju odredbe Statuta "O oporuci" ${ }^{61}$ Kada je riječ o načelu privilegiranja nasljednika, osobitu pozornost zaslužuje posebna odredba kojom se zabrana preferiranja nasljednika jasno odnosila i na ženske ostavitelje. ${ }^{62}$ Prema sadržaju odredbe, nijedna žena nije mogla ostaviti više jednom sinu nego drugima, nijednoj kćeri više nego drugim kćerima. No, po svojoj volji, imala je pravo ostaviti više sinovima nego kćerima. Statut privilegira muške nasljednike kad je posrijedi veličina nasljednog dijela u odnosu na nasljednike ženskog spola. I u ovom je slučaju jednakost i ravnomjernost veličine nasljednog dijela dolazila u obzir samo između nasljednika

56 Margetić, op. cit. u bilj. 25, str. 273.-279.

57 Korčulanski statut, glava XXXVI., str. 18.

58 Korčulanski statut, nova redakcija, glava XXXIX., str. 45.-46.

59 Margetić, op. cit. u bilj 7, str. 211.

6o Cf. Ibid. str. 213.

61 Korčulanski statut, Reformacije korčulanske komune, glava XXXVII., str. 99. 
istog spola, a okolnost da je novim odredbama Statuta bilo potrebno pravni položaj žene ostaviteljice posebno urediti te u vezi s tim izjednačiti s muškim ostaviteljima, pokazuje kako je ovo pitanje zasigurno u praksi srednjovjekovne komune izazivalo brojne sporove. Kao i brojna druga pitanja u kojima norme običajnog prava nisu mogle poslužiti kao korektiv za uređenje novonastalih pravnih odnosa. Vjerojatno je potreba zasebnog uređenja u kasnijoj redakciji Statuta posljedica i neravnopravnog položaja žene koji je dolazio do izražaja u gotovo svim imovinskopravnim odnosima u kojima je žena mogla sudjelovati.

Kada je riječ o neoporučnom nasljeđivanju imovine, u korčulanskom Statutu, kao i među ostalim statutima dalmatinske pravne regije, do izražaja je dolazilo načelo reprezentacije. Prema tome, ako je netko od sinova ostavitelja imao sina ili sinove, unuka ili unuke, oni su prema načelu reprezentacije nasljeđivali oca, tj. djeda, u dijelu imovine koji je imao pripasti njihovu ocu, tj. djedu i tako dalje prema liniji krvnog srodstva. ${ }^{63}$ Interesantno je spomenuti, s obzirom na spomenute odredbe o neravnopravnom položaju žena u imovinskopravnim odnosima, kako je Statut priznavao unukama pravo reprezentacije njihova umrlog oca u nasljeđivanju djeda, ali samo uz pretpostavku da njihov otac nije iza sebe ostavio mušku djecu, tj. da te unuke nisu imale braće. ${ }^{64}$ Nadalje se podrednost pravnog položaja ženskih nasljednika očituje u sadržaju nastavke odredbe. Ako netko od braće ne bi imao sina ili sinove (dakle, ostaviteljeve unuke), nego bi imao kćer ili kćeri, one su imale dobiti dio iza svog oca kao što je dobivao svaki brat. Može se zaključiti kako su unuci koji su potjecali od muških nasljednika ostavitelja imali prednost pred kćerima ostavitelja. Drugim riječima, iz sadržaja ove kompleksne odredbe proizlazi da su kćeri nasljeđivale umrlog oca samo ako nisu imale braće te ako umrla braća nisu imala muške nasljednike. Nadalje se pri određivanju veličine nasljednog dijela primjenjivalo spomenuto načelo nepreferiranja nasljednika istog nasljednog reda.

Ako su braća imala sestru ili sestre, preuzimanjem nasljednog dijela morala su preuzeti i obvezu udaje sestre do osamnaeste godine njezina života. Ako pak to ne bi učinili, mogle su se one same udati uz savjet svojih srodnika i dobiti dio očeve imovine obračunat prema glavama. Iz ove odredbe jasno se vidi obveza sina koji preuzima nasljedni dio preuzeti i brigu oko sestre, tj. omogućiti joj obiteljski život nakon smrti oca. Statut je osiguravao žensku djecu u slučaju u kojem braća očito nisu željela preuzeti skrb oko njihove udaje na način da im se morao dati dio ostavine kako bi vjerojatno s tim dijelom ostvarile miraz i stupile u brak. Statut nije jasno utvrdio što se događalo ako žena nije tijekom života stupila u brak, neovisno o tome je li to posljedica njezine volje ili nedostatka imovine za osiguranje miraza, no pomaže nam odredba Trogirskog statuta koja je u takvom slučaju predviđala samostanski život žene. ${ }^{65}$ Analize odredbe 98. nove redakcije navodi na zaključak kako su samo neudane žene imale pravo sudjelovati u nasljeđivanju umrlih roditelja. ${ }^{6}{ }^{6}$ Ako su otac i majka ili braća udali svoju kćer, odnosno sestru, ona se nije mogla nakon očeve i majčine smrti vratiti na očevinu ili tražiti što iz spomenute očeve imovine, osim ako je imala odgovarajuću ispravu na osnovi oporuke ili druge

63 To dokazuje da potomci nasljeđuju po vlastitom pravu (iure proprio), a ne po pravu svog pretka (alieno iure). Vidjeti Klarić, P., Vedriš, M., Građansko pravo: opći dio, stvarno pravo, obvezno i nasljedno pravo, Narodne novine, Zagreb, 2014., str. 727., Gavella, N., Belaj, V., Nasljedno pravo, Narodne novine, Zagreb, 2008., str. 206.-207.

65 Vidjeti više: Trogirski statut.

66 Korčulanski statut, nova redakcija, gl. XCVIII., str. 63.; Ako su otac i majka ili braća udali svoju kćer odnosno sestru, ona se nije mogla nakon očeve i majčine smrti vratiti na očevinu ili tražiti što iz spomenute očeve imovine, osim ako je imala odgovarajuću ispravu na osnovi oporuke ili druge javne isprave. 
javne isprave. ${ }^{67}$ Čini se kako se na tekst ove odredbe nastavlja i odredba 113., nove redakcije koja ju pobliže definira na način da udanim ženama koje nemaju oca ili brata, a udale su se uz miraz koji je namirio jedan od krvnih srodnika ili srodnik po tazbini, zabranjuje tražiti bilo što drugo od očeve i majčine imovine, tj. zabranjuje joj se iznad miraza sudjelovati u nasljeđivanju roditelja.

Zanimljiva je odredba stare redakcije koja favorizira djecu rođenu u prvom braku iako su ženskog spola u odnosu na sinove rođene u kasnije sklopljenim brakovima ostavitelja gdje svi nasljednici (dakle, neovisno o spolu) imaju pravo naslijediti jednak nasljedni dio ${ }^{68}$ Ista je odredba usvojena i novijom redakcijom Statuta s dodatkom da isto pravilo vrijedi i u slučaju smrti žene koja ima zakonite nasljednike, sinove i kćeri, s jednim ili više muževa. ${ }^{69} \mathrm{U}$ ovoj odredbi ponovno dolazi do izražaja nasljednopravni tip koji omogućuje nasljeđivanje ženskim potomcima, u ovom slučaju, čak ravnopravno s muškim nasljednicima.

Ako je ostavitelj umro bez potomaka, a nije načinio oporuku, sva njegova imovina imala je pripasti ocu, a ako nema oca, bratu, braći ili njihovim potomcima. U slučaju kada ostavitelj nije imao ni braću ni potomke, nasljeđivao bi ga njegov najbliži srodnik. ${ }^{70}$ Novijom redakcijom Statuta dopunjena je završna rečenica odredbe kojom je nasljedno pravo osigurano isključivo najbližem srodniku s očeve strane. ${ }^{71} \mathrm{Iz}$ navedene odredbe, ali i iz većine prethodno analiziranih, može se zaključiti kako je oporuka predstavljala primarni temelj nasljeđivanja, a statutarna pravila primjenjivala bi se u svim slučajevima gdje oporuka nije sastavljena ili gdje je ostavitelj oporučno raspolagao nekretninama iznad Statutom navedenog ograničenja. ${ }^{72}$ Svakom oporučitelju Statutom je bilo dopušteno oporučno raspolagati samo četvrtim dijelom nepokretnih dobara kako bi se osigurali nužni nasljednici, tj. potomci u slučaju da ih otac ne obuhvati oporukom. S tim u vezi upućujemo na glavu 37. knjige reformacija kojom je određeno da bez obzira na statutarne odredbe, svaki čovjek smije i može oporukom ostaviti više sinu ili sinovima nego kćeri ili kćerima. Ali ne može više oporučiti jednom sinu nego drugim, ni jednoj kćeri u odnosu na druge kćeri. Ta je odredba derogirana glavom 131. iz knjige reformacija i uvrštena u Statut. ${ }^{73}$ Time je, kao što smo to već napomenuli, oporučitelju zabranjeno privilegiranje određenog djeteta u odnosu na ostalu djecu.

Statutom su predviđene i pretpostavke valjanosti oporuke. Navedene su sljedeće: oporučitelj je smio sastaviti oporuku u vrijeme kada je bio zdrav ili bolestan, ali "pri zdravoj pameti" u nazočnosti četiri svjedoka, a ako je bio nazočan javni bilježnik, bila su dovoljna trojica. Ako oporuku nije sastavio javni bilježnik, nego je sastavljena u nazočnosti četiriju svjedoka, nasljednici su bili dužni navesti svjedoke da pristupe komunalnom javnom bilježniku i dvojici sudaca te da pod zakletvom posvjedoče o sadržaju iskazivanja oporučitelja. Javni bilježnik je bio dužan u roku od dvadeset dana od iskaza svjedoka sastaviti javnu ispravu jer je u suprotnom oporuka ništava. Ako nasljednici nisu postupili kako nalaže odredba, tj. uputili svjedoke

67 Knjiga II., gl. XCVIII., str. 149.

68 Korčulanski statut, glava XXXVII., str. 19.

69 Korčulanski statut, nova redakcija, glava XLI., str. 46.

70 Korčulanski statut, stara redakcija, glava XL., str. 19.

71 Korčulanski statut, nova redakcija, glava XLV., str. 47.

72 Korčulanski statut, nova redakcija, glava CXLV., str. 80. 
k javnom bilježniku radi sastavljanja javne isprave, morali su vratiti sve što je nepravedno dobiveno te platiti kaznu komuni u iznosu od deset perpera. ${ }^{74} \mathrm{U}$ slučaju postojanja više oporuka vrijedila bi samo posljednja. Time se nastojalo ostavitelju omogućiti naknadnu izmjenu oporučnih raspoložbi koja je u nekim slučajevima zaista odgovarala promijenjenim okolnostima u obiteljskim odnosima.

Još jedna odredba Statuta uređuje raspolaganje ostavitelja vlastitom imovinom, a odnosi se na izdvajanje određene količine pokretnih dobara za spas duše. Doznajemo kako je ostavina za tu namjenu mogla biti isključivo sastavljena od pokretnina te da njihov obujam nije bio ograničen odredbama Statuta. Stara redakcija Statuta davala je pravo na ovakvu raspoložbu samo ostavitelju, dok je nova redakcija omogućila i ženi da raspolaže imovinom u navedenu svrhu. ${ }^{75}$ Čini se kako se imovina za spas duše redovito ostavljala crkvi te da je u znatnoj mjeri povezana s ulogom crkve koja je uvelike katoličkim crkvenim pravom utjecala na regulaciju obiteljskopravnih odnosa unutar komune, a kako vidimo, i na raspolaganje imovinom za slučaj smrti. Bilo je od iznimne važnosti urediti odnos između crkve i komune, tj. građana komune naročito na području nasljeđivanja nekretnina jer je prije definiranja odredaba Statuta kojima se brani raspolaganje nekretnina u korist crkve, crkva vjerojatno postala vlasnikom velikih zemljišnih površina čime je dolazilo do osiromašenja agrarnog fonda komune. ${ }^{76}$ Odredbom 149. iz knjige reformacija ${ }^{77}$ ukinute su prethodno donesene odredbe stare i nove redakcije Statuta i sa šezdeset glasova za i jednim glasom protiv usvojena je odredba kojom se izvan snage stavljaju prethodno donesene odredbe o zabrani nasljeđivanja nekretnina od strane crkve i omogućuje se ponovno oporučno raspolaganje nekretninama u korist crkve. Sadržaj navedene odredbe kao i uvođenje ovog specifičnog nasljednopravnog instituta ne iznenađuje osobito ako se ima na umu vrlo dominantan utjecaj crkve na regulaciju obiteljskih odnosa unutar dalmatinskih komuna, tim više što primjena istoimenog instituta nije izostala ni u drugim autonomnim dalmatinskim komunama koje su svoje pravne norme nastojale regulirati, kako to ističe Petrak, pod utjecajem rimsko-bizantskog prava. ${ }^{78}$

\section{ZAKLJUČAK}

Premda je rimsko-bizantski sustav nasljeđivanja prema kojem su i muški i ženski potomci imali mogućnost naslijediti umrlog ostavitelja velikim dijelom utjecao na izgradnju hrvatskog nasljednog prava, srednjovjekovni izvori u vezi s tim nisu bili ujednačeni. Dok se pravni sustav koji je dominirao u našim priobalnim gradovima razvijao pod različitim utjecajima rimskog, mletačkoga, dijelom i langobardskog prava, sustav nasljeđivanja svojstven većem dijelu kontinentalne Hrvatske izgrađen je na temeljima ugarskog prava. Oba su pravna područja poznava-

74 Korčulanski statut, stara redakcija, glava XLVI., str. 48.

75 Korčulanski statut, stara redakcija, glava XXXIX., str. 19. i Korčulanski statut, nova redakcija, glava XLIV., str. 47.

76 Vidjeti: Gamulin V., Matijević-Sokol, M., Crkvena organizacija i Statut grada i otoka Korčule, Zbornik radova Znanstvenog skupa Statut grada i otoka Korčule iz 1214., RO za grafičku djelatnost, Zagreb, 1989., str. 217.

77 Korčulanski zbornik, knjiga reformacija, glava CXLIX, str. 134.

78 Više o intestatnom nasljeđivanju pro anima u dalmatinskim statutima u: Petrak, M., Rimsko- bizantsko pravo i intestatno nasljeđivanje pro anima u Splitskom statutu, Splitski statut, iz 13012. godine: Povijest i pravo, Pravni fakultet Sveučilita u Splitu, Split, 2015., str. 255.-271. 
la gotovo istovrsne nasljednopravne institute, no razlika među njima vidljiva je osobito u tome je li pojedini pravni sustav priznavao mogućnost nasljeđivanja i ženskoj lozi.

Kada je riječ o statutima naših priobalnih gradova, teško ih se može podvesti pod jedinstvena obilježja. Priznavanje mogućnosti nasljeđivanja nasljednicima ženske loze te izjednačavanje muških i ženskih nasljednika glede nasljeđivanja cjelokupne imovine rijetko je obilježje statuta pojedinih otočnih komuna dok je češća primjena pravila prema kojem su muški nasljednici nasljeđivali nekretnine, a ženski pokretnu imovinu. Hrvatsko-ugarski Tripartit prvenstveno uređuje nasljednopravne odnose unutar povlaštenih plemićkih zajednica, a ističe se neravnopravnošću položaja ženskih nasljednika u odnosu na mušku lozu. Tripartitom je ozakonjeno pravilo sukladno kojem nekretnine nasljeđuju samo muška djeca, ali je postojala i iznimka prema kojoj je pružena mogućnost nasljedstva i ženskoj lozi. Tako je za nekretnine stečene kraljevskom darovnicom bilo određeno da ih i ženska djeca mogu naslijediti, ako nisu bila isključena od nasljeđivanja voljom prvog stjecatelja.

Nasljednopravno uređenje Korčulanskog statuta donekle odstupa od dvaju spomenutih izvora čija je primjena uspostavljena u ostalim dijelovima Hrvatsko-Ugarskog Kraljevstva, uređujući načelno pravo nasljeđivanja ženskih potomaka, no ipak znatno ograničeno prednošću nasljednika muškog spola. Temelji takvog, posebnog hrvatskog tipa nasljednog prava kako stoji u literaturi, sa sigurnošću su recipirani iz langobardskog prava te su stoga, znatno drukčiji od većine ostalih izvora koji su u velikom dijelu izgrađeni na rimskim pravnim temeljima.

Iz svega navedenog možemo zaključiti kako je nasljednopravno uređenje Korčulanskog statuta intermedijalno rješenje između dvaju prikazanih pravnih okvira. Iako je na prvi pogled moguće steći dojam o podrednom položaju ženskih nasljednika u okviru statutarne regulacije, ipak je mogućnost da ženski nasljednici pod određenim uvjetima nasljeđuju i pokretnu i nepokretnu imovinu obilježje koje ovaj Statut razlikuje od drugih izvora srednjovjekovnog prava. Ima li se na umu kako je navedeno rješenje ostavina izvornog hrvatskog prava još iz razdoblja narodnih vladara, epitet liberalnijeg daje mu još i snažniji značaj.

\section{LITERATURA}

1. Apostolova Maršavelska, M., Zagrebački Gradec, Iura possessosionaria, Zagreb, 1986.

2. Berket, M. et al. (eds.), Statut grada Trogira, Statuta et refomationes cicitatis Traguirii, Književni krug, Split, 1988.

3. Beuc, I., Osorska komuna u pravnopovijesnom svjetlu, Vjesnik historijskih arhiva u Rijeci i Pazinu, god. 1., br. 1953, Državni arhiv u Rijeci - Državni arhiv u Pazinu, Pazin, 1953., str. 5.-161.

4. Cvitanić, A. (ed.), Brački statut, Drugo prošireno dopunjeno i dotjerano izdanje, Književni krug, Split, 2006.

5. Cvitanić, A. (ed.), Hvarski statut, Satuta Communitatis Lesinae, Književni krug Split, 1991.

6. Cvitanić, A. (ed.), Statut grada Splita, Statuta civitatis Spalati, II. dotjerano izdanje, Književni krug, Split, 1987.

7. Cvitanić, A., Iz dalmatinske pravne povijesti, Književni krug, Split, 2002.

8. Cvitanić, A., Korčulanski statut: Statut grada i otoka Korčule (1214-1265), Književni krug, Split, 1995. 
9. Cvitanić, A., Korčulanski statut: Statut grada i otoka Korčule iz 1214. godine, Zagreb - Korčula, 1987.

10. Čepulo, D., Statut Paške općine, Statuta Communitatis Pagi, Zagreb, 2011.

11. Čučković, V., Porodica i porodični odnosi u srednjovjekovnom Dubrovniku, Godišnjak Pravnog fakulteta u Sarajevu, br. 31, 1983.

12. Friedrich Bluhme, Edictus ceteraeque Langobardorum leges: cum constitutionibus et pactis principum Beneventanorum, Hannover, 1869.

13. Gamulin V., Matijević-Sokol, M., Crkvena organizacija i Statut grada i otoka Korčule, Zbornik radova Znanstvenog skupa Statut grada i otoka Korčule iz 1214., RO za grafičku djelatnost, Zagreb, 1989., str. 213.-221.

14. Gavella, N., Belaj, V., Nasljedno pravo, Narodne novine, Zagreb, 2008.

15. Grubišić, S. (ed.), Knjiga statuta, zakona i reformacija grada Šibenika, Muzej grada Šibenika, Šibenik, 1982.

16. Hübner, Rudolf, A History of Germanic Private Law, The Lawbook Exchange, Ltd., New Yersey, 2000.

17. Kaller, Paul, Der Sachsenspiegel in hochdeutscher Ubersetzung, Verlag, C. H. Beck, München, 2002.

18. Kaser, M., Das römische Privatrecht, Erster Abschnitt: Das altrömische, das vorklassische und das klassische Recht, Munich: C. H. Beck, 1955.

19. Klarić, P., Vedriš, M., Građansko pravo: opći dio, stvarno pravo, obvezno i nasljedno pravo, Narodne novine, Zagreb, 2014.

20. Kolanović, J., Križman, M. (eds.), Statuta Iadertina, Zadarski statut sa svojim reformacijama odnosno novim uredbama donesenima do godine 1563, Zadar, 1997.

21. Lanović, M., Privatno pravo Tripartita, Tipografija d.d., Zagreb, 1929.

22. Ljubić, Š., Statuta et leges civitatis Buduae, civitatis Scardonae et civitatis insulae Lesinae, Zagreb, 1882./1883.

23. Margetić, L., O starom hrvatskom nasljednom pravu descendenata, Historijski zbornik, god. XXVXXVI, 1972./1973., str. 273.-279.

24. Margetić, L., Nasljedno pravo descendenata po srednjovjekovnim statutima Šibenika, Paga, Brača i Hvara, Zbornik Pravnog fakulteta u Zagrebu, br. 3, Zagreb, 1972., str. 339.-366.

25. Margetić, L., Hrvatsko srednjovjekovno obiteljsko i nasljedno pravo, Zagreb, 1996.

26. Margetić, L., Iločka pravna knjiga, Zbornik Pravnog fakulteta u Zagrebu, god. 44, br. 1-2, Zagreb, 1994., str. 93.-116.

27. Margetić, L., Krčki (Vrbanski) statut iz 1388., Krk, Povijesno društvo Saveza povijesnih društava Hrvatske, 1988.

28. Margetić, L., Nasljedno pravo descendenata po srednjovjekovnim statutima Šibenika, Paga, Brača i Hvara, Zbornik Pravnog fakulteta u Zagrebu, vol. XXII, br. 3, 1972.

29. Margetić, L., Neoporučno nasljedno pravo u srednjovjekovnoj Istri, Vjesnik historijskih arhiva u Rijeci i Pazinu, Vol. 17, 1972.

30. Margetić, L., Statut rapske komune iz 14. stoljeća = [Statut communis Arbae], Adamić, Rab, Grad Rab, Rijeka, 2004.

31. Margetić, L., Vinodolski zakon $=$ La legge del Vinodol = Das Gesetz von Vinodol $=$ The Vinodol Law, Adamić - Vitagraf, Rijeka - Novi Vinodolski, 1998.

32. Margetić, L., Apostolova Maršavelska, M., Hrvatsko srednjovjekovno pravo: vrela s komentarom, Narodne novine, Zagreb, 1991.

33. Pera, M., Poljički statut, Književni krug, Split, 1988. 
34. Petrak, M., Rimsko-bizantsko pravo i intestatno nasljeđivanje pro anima u Splitskom statutu, Splitski statut iz 1312. godine: Povijest i pravo, Pravni fakultet Sveučilišta u Splitu, Split, 2015.

35. Prijatelj, K., Berket, M., Cvitanić, A., Gligo, V., Statut grada Trogira, Splitski književni krug, Split, 1988.

36. Puchta, G. F., Pandekten, Leipzig, 1848.

37. Radić, Ž., Imovinsko pravo po statutu grada Trogira iz 1322. (doktorska disertacija), 2002.

38. Romac, A., Izvori rimskog prava - latinski tekstovi s prijedvodom, Informator, Zagreb, 1973.

39. Romac, A., Rimsko pravo, Pravni fakultet: Centar za stručno usavršavanje i suradnju s udruženim radom, Zagreb, 1981.

40. Sohm, Rudolf, The Institutes of Roman Law, Chapter II, The law of inheritance, Translated by James Craford Ledlie, Oxford and the Claredon Press, 1892.

41. Sydow, Rudolf von, Darstellung des Erbrechts nach den Grundsätzen des Sachsenspiegels mit Rücksicht auf die verwandten Quellen, Berlin, 1828.

42. Šoljić, A., Šundrica, Z., Veselić, I., Statut grada Dubrovnika, Državni arhiv u Dubrovniku, Dubrovnik, 2002.

43. Zdravčević, A., Iločki statut iz 1525. godine i njegova nasljedno pravna regulacija, doktorski rad, Osijek, 1993. 
Jelena Kasap*

Višnja Lachner"

\section{THE LEGAL REGULATION OF INHERITANCE OF THE KORČULA STATUTE}

\section{Summary}

The legal regulation of inheritance of the Korčula Statute is based on the elements of old Croatian and Slavic law and differs from the regulations in the statutes of other Dalmatian cities that are often the result of the influence of the Byzantine and later the Croatian-Hungarian Tripartite law. The basic characteristic of such a regulation, which Margetic refers to as a succesion descendent law, is the possibility that both male and female descendants inherit the estate of the deceased, but the male descendants have the advantage over women of the same degree of kinship, whereas according to Croatian-Hungarian law, women could not inherit their father's real estate. Furtheron, the paper points out the differences regarding the legal foundations of the inheritance stipulated by the Korčula statute and other important statutes of the Dalmatian cities, and it pays particular attention to the married women's inheritance position in terms of the disposition of their personal goods, i.e. dowry.

Keywords: $\quad$ legal regulation of inheritance, Korčula Statute, statutes of Dalmatian cities, women's inheritance position, dowry

\section{(i) \$}

This work is licensed under a Creative Commons

Attribution-NonCommercial 4.0 International License.

* Jelena Kasap, Assistant professor, Faculty of Law, University of Osijek, Stjepana Radića 13, 31000 Osijek, Republic of Croatia. Email address: jkasap@pravos.hr. ORCID: https://orcid.org/0000-0002-8182-7493.

** Višnja Lachner, Assistant professor, Faculty of Law, University of Osijek, Stjepana Radića 13, 31000 Osijek, Republic of Croatia. Email address: vlachner@pravos.hr. ORCID: https://orcid.org/0000-0002-0661-8931. 